\title{
Influence of cadmium and copper mixtures to rhizosphere bacterial communities
}

\author{
Qirui $\mathrm{An}^{1,+}$, Yunyang $\mathrm{Li}^{1,2,3,}, \mathrm{Na}$ Zheng ${ }^{1,2,{ }^{*}}$, Jincai $\mathrm{Ma}^{1}$, Shengnan $\mathrm{Hou}^{2,3}$, Siyu Sun ${ }^{1}$, Sujing Wang ${ }^{1}$, \\ Pengyang $\mathrm{Li}^{1}$, Xiaoqian $\mathrm{Li}^{1}$, Chunmei Zhao ${ }^{4}$
}

1 Key Laboratory of Groundwater Resources and Environment of the Ministry of Education, College of Environment and Resources, Jilin University, Changchun 130021, China

2 Northeast Institute of Geography and Agricultural Ecology, Chinese Academy of Sciences, Changchun 130102, China

3 University of Chinese Academy of Sciences, Beijing 100049, China

4 Guangdong Provincial Key Laboratory of Environmental Pollution Control and Remediation Technology, Sun Yat-sen University, Guangzhou 510006, China

\section{H I G H L I G H T S}

- The relative abundance of rhizosphere soil bacteria has significantly positive correlation with BCF of $\mathrm{Cd}$ and $\mathrm{Cu}$.

- Obvious variations of predominant species of bacterial communities in rhizosphere soil would emerge in the additions with different concentrations of $\mathrm{Cd}-\mathrm{Cu}$ mixtures.

- In the additions with $\mathrm{Cd}$ and $\mathrm{Cu}$, the mean of rhizosphere soil bacterial community diversity index was ranked as: $\mathrm{Cu}$ alone $>\mathrm{Cd}-\mathrm{Cu}$ mixtures $>$ Cd pollution.

- The PCA and PERMANOVA analysis showed that $\mathrm{Cu}$ may be the main factor changing the composition of rhizosphere soil bacteria.

\section{ARTICLE INFO}

Article history:

Received December 9, 2020

Revised October 30, 2021

Accepted November 15, 2021

Keywords:

Cadmium

Copper

High-throughput sequencing

Bacterial community structure
GRAPHICAL ABSTRACT

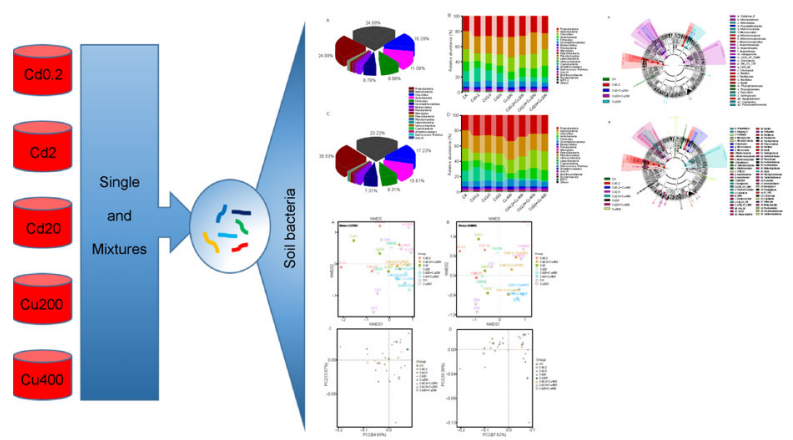

\begin{abstract}
A B S T R A C T
To study the effects of combined $\mathrm{Cd}$ and $\mathrm{Cu}$ pollution on rhizosphere bacterial community. Highthroughput sequencing was used to examine the response of rhizosphere bacterial communities to heavy-metal stress under single and mixed pollution of cadmium (Cd) and copper (Cu). With additions of $\mathrm{Cd}$ and $\mathrm{Cu}$, the mean diversity index of rhizosphere bacterial community was in the order $\mathrm{Cu}$ alone $>\mathrm{Cd}-\mathrm{Cu}$ mixtures $>\mathrm{Cd}$ alone. In all $\mathrm{Cd}$ and $\mathrm{Cu}$ treatments, the dominant phyla were Proteobacteria, Actinobacteria, Chloroflexi and Acidobacteria. In the additions with different concentrations of $\mathrm{Cd}$-Cu mixtures, LEfSe indicated that there were differences in the predominant species of rhizosphere bacterial communities. Some genera such as Streptomyces and Microbacterium belonging to Actinobacteria as biomarkers were significantly enriched in both control and treatments, while some genera such as Pseudoxanthomonas and Rhodopseudomonas belonging to Proteobacteria as biomarkers were observed to be enriched in the additions with single and mixture of $\mathrm{Cd}$ and $\mathrm{Cu}$. According to the Nonmetric multidimensional scaling (NMDS) analysis, the structure of rhizosphere bacterial community was different between treatments and the CK. Principal Component Analysis (PCA) and permutational multivariate analysis of variance (PERMANOVA) showed that there were significant differences among treatments $(p<0.01)$, and that the addition of $\mathrm{Cu}$ might be the primary factor affecting the composition of rhizosphere bacterial communities.
\end{abstract}

(c) Higher Education Press 2021

\footnotetext{
* Corresponding author

E-mail address: zhengnalzz@neigae.ac.cn, zhengnalzz@jlu.edu.cn
}

(N. Zheng)

${ }^{\dagger}$ Qirui An and Yunyang Li contributed equally to this work. 


\section{Introduction}

Because of rapid industrialization and anthropogenic activity, heavy metal pollution of soils has become a world-wide environmental issue (Anjum et al., 2015; Xie et al., 2018). In particular, the application of fertilizers and pesticides leads to the accumulation of metals such as cadmium (Cd) and copper (Cu) in soils (Roy and Mcdonald, 2015). With high accumulation in soil, $\mathrm{Cu}$ can be transferred through the food chain and cause serious damage to the human liver, endocrine system and kidneys (Tang et al., 2019; Guo et al., 2020). Cd pollution significantly adversely affects crops, and its accumulation in agricultural products may directly cause serious disease in soil (Shi et al., 2020).

To date, many studies have investigated the effect of combinations of heavy metal on vegetable (An et al., 2004; Feng et al., 2018; Xie et al., 2018; Greco et al., 2019). Hou et al. (2018) found that the synergistic reaction between $\mathrm{Cd}$ and Cu might exist, which lead to more harmful effects to vegetables. In addition, the concentration of $\mathrm{Cd}$ and $\mathrm{Cu}$ had an obvious impact on the occurrence of antagonism and synergism, and the research had found that the antagonistic reaction and synergistic reaction emerged with low concentrations and higher concentrations of $\mathrm{Cd}$ and $\mathrm{Cu}$, respectively (Chu et al., 2006). Study had found that $\mathrm{Cu}$ and $\mathrm{Cd}$ are toxic to plants by competing with other essential elements to bind the active sites of enzymes (Feng et al., 2018). Sunda and Huntsman (1998) also found that metal coordination sites on the cell surface are never entirely specific for a single metal or nutrient, and competition for membrane transport sites and intracellular binding sites can occur for metals with similar ionic radii and coordination geometry. The rhizosphere is one of the most active interfaces in ecosystems because many soil biota are involved in complex biological and ecological processes (Tian et al., 2020). The beneficial interactions between plant roots, and soil microorganisms can improve the tolerance and accumulation ability of plants to metals. Soil microbial community-plant synergism can increase the nutrient supply and enhance the tolerance of plants to excessive toxic trace metals in contaminated soil (Kidd et al., 2009; Wenzel, 2009). Studies have also shown that different heavy metal resistant microorganisms affect plant growth and metal absorption through different mechanisms, including plant hormone production and soil environment improvement (Ju et al., 2019). At present, studies have found that the diversity and structure of rhizosphere microorganisms have significantly changed due to single heavy metal pollution (Gołebiewski et al., 2014; Schneider et al., 2017). But additional research is needed on the effects of combined $\mathrm{Cd}$ and $\mathrm{Cu}$ pollution on rhizosphere bacterial community.

Soil microorganisms are essential components in most terrestrial ecosystems due to their roles in mineral cycles and their living habitats around plant roots. Moreover, soil microbes can directly increase plant biomass production and tolerance to heavy metals (Hansda et al., 2017).
However, heavy metal stress can affect the survival, population and diversity of microorganisms and can reduce growth in plants (Siripornadulsil and Siripornadulsil, 2013; Teste et al., 2017; Li et al., 2018). It is reported that the pollution of $\mathrm{Cd}$ and $\mathrm{Cu}$ would decrease microbial biomass and soil enzyme activities (Giller et al., 2009; Wyszkowska et al., 2013). Song et al. (2018a) found that soil microbial biomass decreased with increasing soil heavy metal ( $\mathrm{Cd}, \mathrm{Cu}$ ) concentrations in both long-term and short-term experiments, and the interaction between soil physicochemical factors $(\mathrm{pH}$, $\mathrm{TN}, \mathrm{TC}$ ) and heavy metals ( $\mathrm{Cd}, \mathrm{Cu}$ ) played a major role in change in the bacterial community in long-term polluted soil. Vegetables play important roles in our daily diet as economic crops. Vegetables take up heavy metals through two ways, including absorbing them from the contaminated soils, as well as from deposits on parts of the vegetables exposed to the air from polluted environments (X. Liu et al., 2013). There have been many studies on the adverse effects of heavy metal to vegetable (Liu et al., 2013; Hou et al., 2018; Gong et al., 2019). However, few reports in the rhizosphere bacterial community of vegetable on combined pollution of $\mathrm{Cd}$ and $\mathrm{Cu}$. Pakchoi is one of the most important worldwide leaf vegetables, and study has identified some genotypes of pakchoi with significantly different capacities of $\mathrm{Cd}$ uptake and accumulation under Cd exposure (Zhou et al., 2016). Therefore, the mechanisms by which heavy metal stress affects the diversity and structure of rhizosphere microbial communities of pakchoi and how those communities respond to the stresses of single and combined heavy metals need to be investigated further.

In the present study, a pot experiment with pakchoi and different concentrations of $\mathrm{Cd}$ and $\mathrm{Cu}$ alone and in mixtures was conducted. The specific aims of this study were the following: (1) to determine the effects of $\mathrm{Cd}-\mathrm{Cu}$ mixtures on community diversity of rhizosphere bacteria and identify biomarkers taxa; and (2) to evaluate how $\mathrm{Cd}$ and $\mathrm{Cu}$ pollution alter the structure of rhizosphere bacterial communities using Nonmetric multidimensional scaling, Principal Component Analysis and permutational multivariate analysis of variance.

\section{Materials and methods}

\subsection{Study area and test treatment}

The pot experiment was conducted in a greenhouse situated in North-east Institute of Geography and Agroecology, Chinese Academy of Sciences, Changchun, China $\left(44^{\circ} 0^{\prime} 11^{\prime \prime} \mathrm{N}, 125^{\circ} 23^{\prime} 58^{\prime \prime} \mathrm{E}\right)$. The temperature in the greenhouse during the study ranged from 18 to $30^{\circ} \mathrm{C}$, and the air humidity was between $55 \%$ and $80 \%$. The clay loam soil used to cultivate pakchoi (provided by the seed breeding station in Dehui City, Jilin Province) was from farmland in Changchun, China. Soil physicochemical properties were the following: $\mathrm{pH}$ 7.45 , organic matter $2.43 \%$, total nitrogen $1.05 \mathrm{~g} \mathrm{~kg}^{-1}$, total phosphorus $0.58 \mathrm{~g} \mathrm{~kg}^{-1}$, and the contents of $\mathrm{Cd}$ and $\mathrm{Cu}$ 
were 0.09 and $19.64 \mathrm{mg} \mathrm{kg}^{-1}$. After the soil was air-dried and passed through a $2 \mathrm{~mm}$ sieve, $\mathrm{Cd}$ was added as $\mathrm{Cd}\left(\mathrm{NO}_{3}\right)_{2} \cdot 4\left(\mathrm{H}_{2} \mathrm{O}\right)$, and $\mathrm{Cu}$ was added as $\mathrm{Cu}\left(\mathrm{NO}_{3}\right)_{2} \cdot 3\left(\mathrm{H}_{2} \mathrm{O}\right)$. To ensure normal growth of pakchoi, fertilizer was added as $0.75 \mathrm{~g} \mathrm{NH}_{4} \mathrm{NO}_{3}$ and $0.44 \mathrm{~g} \mathrm{~K}_{2} \mathrm{SO}_{4}$ per $\mathrm{kg}$ soil. The specific experimental design details are shown in our previous study (Hou et al., 2018).

In this study, the Cu treatments included low $\left(200 \mathrm{mg} \mathrm{kg}^{-1}\right)$ and high $\left(400 \mathrm{mg} \mathrm{kg}^{-1}\right)$ additions, and the Cd treatments included low $\left(0.2 \mathrm{mg} \mathrm{kg}^{-1}\right)$, medium $\left(2.0 \mathrm{mg} \mathrm{kg}^{-1}\right)$, and high $\left(20 \mathrm{mg} \mathrm{kg}^{-1}\right)$ additions. The treatments with mixtures of $\mathrm{Cu}$ and $\mathrm{Cd}$ were the following (all concentrations in $\left.\mathrm{mg} \mathrm{kg}^{-1}\right)$ : (Cd $0.2+\mathrm{Cu} 200 ; \mathrm{Cd} 2.0+\mathrm{Cu} 200 ; \mathrm{Cd} 20+\mathrm{Cu} 200 ; \mathrm{Cd} 0.2+\mathrm{Cu}$ 400; Cd 2.0 + Cu 400; Cd $20+\mathrm{Cu} 400 \mathrm{mg} \mathrm{kg}^{-1}$ ). The control (CK) did not receive heavy metal additions, each treatment was prepared in hexaplicate. The pakchoi was harvested after 60 days, and using a toothbrush to collect rhizosphere soil within approximately $2 \mathrm{~mm}$ of the root surfaces. All collected soil samples were homogenized by sieving them through a 2-mm mesh sieve to remove stones and plant roots (Yang et al., 2019). One part was air-dried and stored at $4^{\circ} \mathrm{C}$ for physicochemical analyses, and the other part was stored at $-80^{\circ} \mathrm{C}$ for high-throughput sequencing of the soil microbes. The main properties of the experimental soil are shown in Table 1.

2.2 Determination of the physicochemical properties and heavy metals of soil

Potentiometric (pHS-3B, Leici, Shanghai, China) was used to determine the $\mathrm{pH}$ value of the soil (soil-water ratio, 1:2.5), and its organic matter content was determined using the WalkleyBlack method (Sun et al., 2013; Gan et al., 2017). Soil total nitrogen was measured by the micro-Kjeldahl method (Mani et al., 2012). Soil total phosphorus was measured using the ammonium-molybdate-spectrophotometric method (Guan et al., 2014).

To determine total $\mathrm{Cd}$ and $\mathrm{Cu}$ contents, soil samples were air-dried at ambient temperature, crushed and passed through a $0.149-\mathrm{mm}$ nylon sieve and then digested in triplicate with a mixture of $\mathrm{HF}, \mathrm{HClO}_{4}$ and $\mathrm{HNO}_{3}$ (Liu et al., 2013). The total concentration of soil $\mathrm{Cd}$ was determined by graphite furnace atomic absorption spectroscopy (GFAAS; AA-6300C, Shimadzu, Japan). The total concentration of soil $\mathrm{Cu}$ was determined by flame (air acetylene) atomic absorption spectroscopy (FAAS; AA-6300C, Shimadzu, Japan) (Chaudhuri et al., 2003; Xie et al., 2009; Zhao et al., 2019).

2.3 DNA extraction, Illumina MiSeq, and analysis of sequencing data

Total DNA was extracted from $0.5 \mathrm{~g}$ of rhizosphere soil using a DNA isolation kit (Omega, Norcross, GA, USA). The DNA was quantified using a NanoDrop NC 2000 (Thermo Scientific, Waltham, MA, USA), and DNA quality was assayed on $0.8 \%$ agarose gel via electrophoresis. Take the bacterial rRNA target sequence as the target, and the corresponding primers were designed according to the conserved regions in the sequence. Sample-specific bar coded sequences were added. Polymerase chain reaction was used amplify of the variable V3-V4 region of the bacterial 16S rRNA gene using the forward primer 338F (ACTCCTACGGGAGGCAGCA) and reverse primer 806R (GGACTACHVGGGTWTCTAAT). The PCR amplification program was the following: $95^{\circ} \mathrm{C}$ for $3 \mathrm{~min}$; 25 cycles of $30 \mathrm{~s}$ at $95^{\circ} \mathrm{C}, 30 \mathrm{~s}$ at $55^{\circ} \mathrm{C}$, and $30 \mathrm{~s}$ at $72^{\circ} \mathrm{C}$; and 5 min of final elongation at $72^{\circ} \mathrm{C}$. The PCR amplification used NEB's (USA) Q5 high-fidelity DNA polymerase, and the amplified products were detected by $2 \%$ agarose gel electrophoresis. The recovery uses AXYGEN's (USA) gel recovery kit and refers to the preliminary electrophoresis. The

Table 1 Main characteristics of the experimental soil (mean $\pm S D$ ).

\begin{tabular}{|c|c|c|c|c|}
\hline Treatments & $\mathrm{pH}$ & Organic matter (\%) & $\mathrm{Cd}\left(\mathrm{mg} \mathrm{kg}^{-1}\right)$ & $\mathrm{Cu}\left(\mathrm{mg} \mathrm{kg}^{-1}\right)$ \\
\hline CK & $7.45 \pm 0.06^{a}$ & $2.43 \pm 0.12^{\mathrm{ab}}$ & $0.16 \pm 0.02^{\mathrm{c}}$ & $19.64 \pm 0.10^{c}$ \\
\hline $\mathrm{Cd} 0.2$ & $7.42 \pm 0.29^{a}$ & $2.39 \pm 0.09 a b$ & $0.23 \pm 0.01^{c}$ & $20.70 \pm 0.27^{c}$ \\
\hline $\mathrm{Cd} 2.0$ & $7.40 \pm 0.09^{a}$ & $2.08 \pm 0.14^{b}$ & $2.32 \pm 0.54^{c}$ & $19.70 \pm 0.91^{c}$ \\
\hline $\mathrm{Cd} 20$ & $7.38 \pm 0.20^{a}$ & $2.04 \pm 0.05^{b}$ & $14.37 \pm 6.72^{b}$ & $20.53 \pm 1.16^{c}$ \\
\hline Cu200 & $7.36 \pm 0.06^{a}$ & $2.47 \pm 0.23^{a}$ & $0.05 \pm 0.01^{\mathrm{c}}$ & $289.48 \pm 130.13^{b}$ \\
\hline Cu400 & $7.41 \pm 0.06^{a}$ & $2.23 \pm 0.28^{\mathrm{ab}}$ & $0.08 \pm 0.02^{c}$ & $236.08 \pm 45.94^{b}$ \\
\hline $\mathrm{Cd} 0.2+\mathrm{Cu} 200$ & $7.34 \pm 0.25^{a}$ & $2.38 \pm 0.12^{\mathrm{ab}}$ & $0.25 \pm 0.05^{c}$ & $193.82 \pm 29.85^{b}$ \\
\hline $\mathrm{Cd} 2.0+\mathrm{Cu} 200$ & $7.27 \pm 0.11^{a}$ & $2.26 \pm 0.19^{a b}$ & $0.91 \pm 0.10^{c}$ & $123.52 \pm 20.34^{c}$ \\
\hline $\mathrm{Cd} 20+\mathrm{Cu} 200$ & $7.35 \pm 0.19^{a}$ & $2.08 \pm 0.04^{b}$ & $22.21 \pm 8.25^{a}$ & $282.32 \pm 199.29^{b}$ \\
\hline $\mathrm{Cd} 0.2+\mathrm{Cu} 400$ & $7.54 \pm 0.04^{a}$ & $2.12 \pm 0.11^{b}$ & $0.25 \pm 0.02^{c}$ & $379.31 \pm 79.94^{a}$ \\
\hline $\mathrm{Cd} 2.0+\mathrm{Cu} 400$ & $7.46 \pm 0.26^{a}$ & $2.36 \pm 0.12^{a b}$ & $1.10 \pm 0.19^{c}$ & $194.65 \pm 146.40^{b}$ \\
\hline $\mathrm{Cd} 20+\mathrm{Cu} 400$ & $7.39 \pm 0.04^{a}$ & $2.20 \pm 0.06^{b}$ & $20.24 \pm 0.60^{a}$ & $488.98 \pm 134.62^{a}$ \\
\hline
\end{tabular}

Note: Different letters in the upper right corner denote significant differences among treatments $(p<0.05)$. 
PCR amplification and recovery products were subjected to fluorescence quantification, the fluorescence reagent was Quant-iT PicoGreen dsDNA Assay Kit, and the quantification instrument was Microplate reader (BioTek, FLx800) (Zhao et al., 2020).

The amplified products were sent to Shanghai Personal Biotechnology Co., Ltd. (Shanghai, China) for sequencing on the Illumina MiSeq high-throughput sequencing platform. Quantitative Insights into Microbial Ecology (QIIME) (v1.8.0, http://qiime.org/) was used to identify the sequences. USEARCH (v5.2.236, http://www.drive5.com/usearch/) was called by QIIME to check and eliminate the chimeric sequences (Huang et al., 2020). The results obtained by sequencing were filtered using QIIME (Lauber et al., 2008). To cluster operational taxonomic unit (OTUs), the Uclust method in QIIME was used to cluster high-quality sequences by $97 \%$ similarity and select the longest sequence of each class as the representative sequence (Edgar, 2010). The default parameters in QIIME were used, and the representative sequence of an OTU class was compared with the template sequences of a corresponding database (in this study, the Greengenes database: http://greengenes.secondgenome.com/) to obtain the taxonomic information. For different types of sequences, the template sequences of specific databases were used to OTUs (Zhao et al., 2019). To obtain the taxonomic information on each OUT, the BLAST method in QIIME was used to compare sequences in the database.

\subsection{Statistical analysis}

To assess species richness and diversity, the diversity indices Chao1, ACE, and Shannon were calculated using QIIME
(Jiang et al., 2019). Following one-way ANOVA, a least significant difference test was used to test means for significant differences at $p<0.05$. The analysis was performed in SPSS (V26.0). The LEfSe method was used to determine the features as biomarkers which can explain significant differences between different treatments. An LDA threshold score $>3.0$ and a significance value of 0.05 were set (Wang et al., 2020). The PCA, NMDS, and other graphs were analyzed using R software (V3.6.3) and the Genescloud platform (https://www.genescloud.cn/). QIIME was used to perform PERMANOVA based on Bray-Curtis similarity indices, and 999 permutation tests to determine whether the differences between groups were statistically significant. The 16S rRNA data have been submitted to the GenBank (https:// www.ncbi.nlm.nih.gov/genbank/) under the accession number PRJNA721125 (Registration date: 11-Apr-2021).

\section{Results}

3.1 Abundance and structural diversity of rhizosphere bacterial communities

A total of 76104 OTUs were identified following Illumina MiSeq sequencing. Venn diagram in Fig. 1 show the numbers of shared and unique OTUs in different treatments. As shown in Fig. 1A, 5595 OTUs were shared among the five groups. The number of unique OTUs in the treatment of $\mathrm{Cd} 0.2$ was similar to that in CK, whereas only two unique OTUs were identified in the treatment of $\mathrm{Cd} 20$. Analogously, there were more unique OTUs numbers in the mixed treatment of $\mathrm{Cd} 0.2+\mathrm{Cu} 200$ than in the $\mathrm{Cd} 20+\mathrm{Cu} 200$. As shown in Fig. 1B, the number of
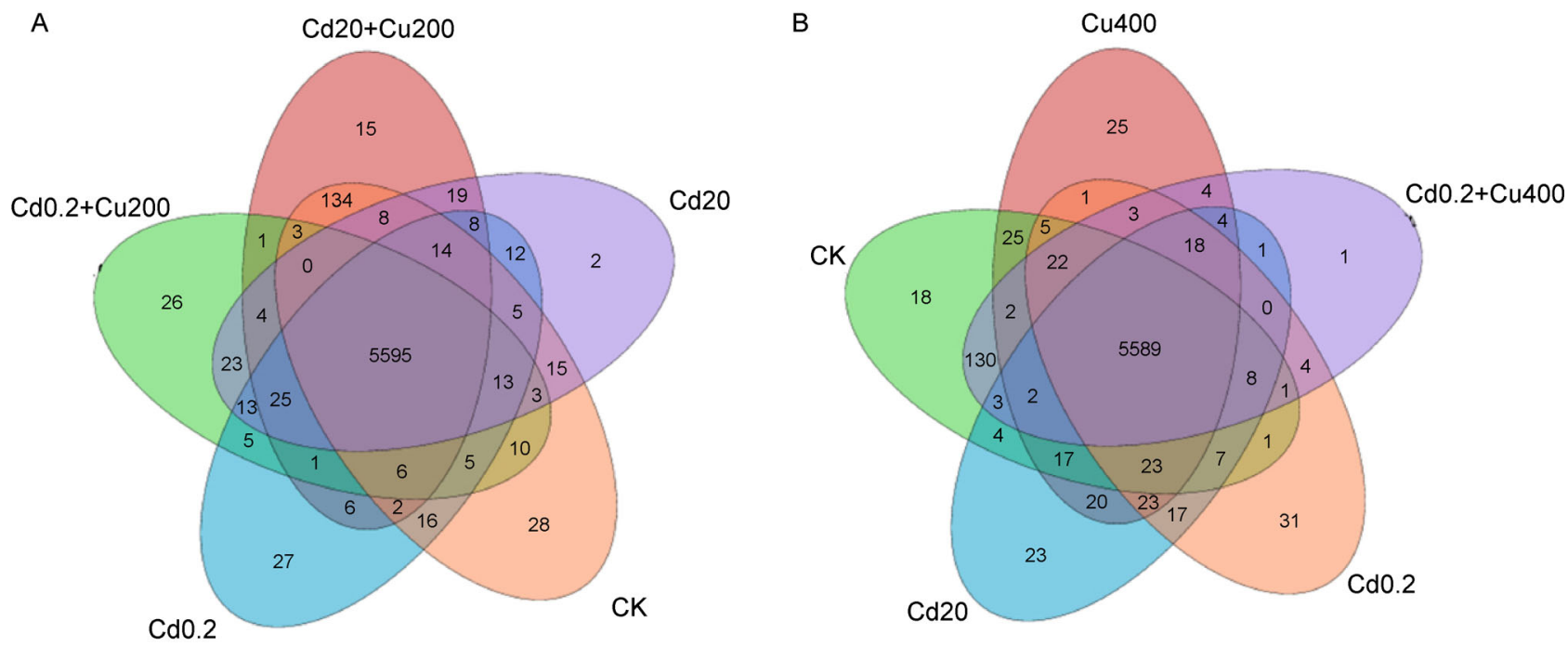

Fig. 1 Venn diagram of OTU numbers in rhizosphere soil samples (A: CK, treatment of Cd $\left(0.2,20 \mathrm{mg} \mathrm{kg}^{-1}\right)+\mathrm{Cu}\left(0,200 \mathrm{mg} \mathrm{kg}{ }^{-1}\right)$; B: $\mathrm{CK}$, treatment of $\mathrm{Cd}\left(0.2,20 \mathrm{mg} \mathrm{kg}^{-1}\right), \mathrm{Cu} 400 \mathrm{mg} \mathrm{kg}^{-1}$ and $\mathrm{Cd} 0.2 \mathrm{mg} \mathrm{kg}^{-1}+\mathrm{Cu} 400 \mathrm{mg} \mathrm{kg}^{-1}$. CK in A and B were the same control group. Different colors represent different treatments, the numbers of overlapping sections represent the number of OTUs common in multiple samples, and the numbers of non-overlapping sections represent the number of OTUs unique to the corresponding sample). 
unique OTUs in the treatments with only $\mathrm{Cd}$ or $\mathrm{Cu}$ was similar to that in CK. The treatment of $\mathrm{Cd} 0.2+\mathrm{Cu} 400$ had the smallest number unique OTUs, with only one. Notably, in the treatments with different $\mathrm{Cd}$-Cu mixtures (Fig. $1 \mathrm{~A}$ and $1 \mathrm{~B}$ ), the number of shared OTUs among all treatments was much greater than the number of unique OTUs in each treatment.

Table 2 lists the richnesss and diversity indices of rhizosphere bacterial communities in treatments with varying amounts of $\mathrm{Cd}$ and $\mathrm{Cu}$. The richness and diversity indices (Chao1, ACE and Shannon indices) were not significantly different in the different treatments $(p>0.05)$. Thus, only the average value was compared in each treatment. In the heavy metal treatments, the Shannon index changed slightly compared with that in CK. In the treatments with only $\mathrm{Cd}$ or $\mathrm{Cu}$, the Chao1 and ACE richness indice decreased compared with those in the control. However, in the treatments with mixtures of $\mathrm{Cd}$ and $\mathrm{Cu}$, the Chao1 and ACE indices were similar to those in the control. In addition, the bacterial community diversity indices decreased (after the application

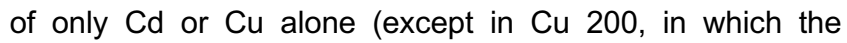
decrease was not significant; Table 2). In the comparisons between single $\mathrm{Cd}$ treatments and those with $\mathrm{Cd}$ at the same level mixed with the low level of $\mathrm{Cu}$, the mean bacterial community richness indices were higher in the mixtures than with Cd alone: $\mathrm{Cd} 0.2+\mathrm{Cu} 200>\mathrm{Cd} 0.2 ; \mathrm{Cd} 2.0+\mathrm{Cu} 200>\mathrm{Cd}$ 2.0; Cd 20+ Cu 200>Cd 20. However, in the same type of comparisons with $\mathrm{Cu}$, the mean bacterial community richness index in the combined treatments was slightly smaller.

3.2 Effects of heavy metals on dominant phyla of bacterial communities

Figure $2 \mathrm{~A}$ and $2 \mathrm{C}$ show the relative abundances of phyla of bacteria in all treatments. In the treatments with only $\mathrm{Cd}$ or mixtures of $\mathrm{Cd}\left(0.2,2.0,20 \mathrm{mg} \mathrm{kg}^{-1}\right)$ and a low level of $\mathrm{Cu}$ $\left(200 \mathrm{mg} \mathrm{kg}^{-1}\right)$ (Fig. 2A), there were six dominant phyla: Proteobacteria (24.9\%), Actinobacteria (24.1\%), Chloroflexi $(16.3 \%)$, Acidobacteria (11.1\%), Firmicutes $(9.89 \%)$ and Gemmatimonadetes $(6.79 \%)$. In treatments with only $\mathrm{Cd}$ or mixtures of $\mathrm{Cd}\left(0.2,2.0,20 \mathrm{mg} \mathrm{kg}^{-1}\right)$ and a high level of $\mathrm{Cu}$ $\left(400 \mathrm{mg} \mathrm{kg}^{-1}\right)$ (Fig. 2C), the dominant bacteria phyla were also Proteobacteria (26.5\%), Actinobacteria (23.2\%), Chloroflexi (17.2\%), Acidobacteria (10.6\%), Firmicutes $(8.31 \%)$ and Gemmatimonadetes (7.31\%).

Figure 2B and 2D show the abundance of phyla in individual treatments. The lowest abundance of Proteobacteria $(19.9 \%)$ was in the control, whereas the highest abundance $(33.9 \%)$ was in the $\mathrm{Cu} 400 \mathrm{mg} \mathrm{kg}^{-1}$ treatment. Notably, although Firmicutes was a dominant phylum in the control $(14.0 \%)$ and $\mathrm{Cd}$ only treatments $(11.5 \%$ to $18.2 \%)$, it only accounted for $2.91 \%$ in $\mathrm{Cu} 200 \mathrm{mg} \mathrm{kg}^{-1}$ treatment (Fig. 2B) and $1.23 \%$ in $\mathrm{Cu} 400 \mathrm{mg} \mathrm{kg}^{-1}$ treatment (Fig. 2D). In addition, in the mixed treatments with $\mathrm{Cd}\left(0.2,2.0,20 \mathrm{mg} \mathrm{kg}^{-1}\right)$ and $\mathrm{Cu}\left(400 \mathrm{mg} \mathrm{kg}^{-1}\right)$, the relative abundance of Firmcutes accounted for only $1.23 \%$ to $3.13 \%$ (Fig. 2D).

3.3 Biomarkers of soil bacterial community under heavy metal mixtures pollution

In this study, the specific bacteria from phylum to genus within different treatments were evaluated by conducting biomarker analysis using the LEfSe method (Wang et al., 2020). As shown in Fig. 3A, 30-two bacterial clades showed significant differences with a LDA threshold of 3.0. Similarly, as shown in Fig. 3B, 60-two bacterial clades showed significantly differences with a LDA threshold of 3.0.

Table 2 Bacterial community diversity index (sequence similarity 97\%) level (mean \pm SD).

\begin{tabular}{|c|c|c|c|c|}
\hline Treatments & No. OTUs & Chao1 & ACE & Shannon \\
\hline CK & $3386 \pm 237^{a}$ & $4096 \pm 241^{a b}$ & $4491 \pm 292^{a}$ & $10.31 \pm 0.25^{a b}$ \\
\hline $\mathrm{Cd} 0.2$ & $3003 \pm 420^{a}$ & $3782 \pm 373^{a b}$ & $4012 \pm 546^{a}$ & $9.92 \pm 0.59^{b}$ \\
\hline $\mathrm{Cd} 2.0$ & $3142 \pm 390^{a}$ & $3756 \pm 453^{a b}$ & $4101 \pm 529^{a}$ & $10.15 \pm 0.46^{a b}$ \\
\hline $\mathrm{Cd} 20$ & $3048 \pm 543^{a}$ & $3523 \pm 934^{b}$ & $3789 \pm 578^{a}$ & $10.28 \pm 0.23^{a b}$ \\
\hline Cu200 & $3363 \pm 159^{a}$ & $4245 \pm 135^{a b}$ & $4556 \pm 160^{a}$ & $10.54 \pm 0.05^{a}$ \\
\hline Cu400 & $2958 \pm 327^{a}$ & $3595 \pm 554$ ab & $3928 \pm 657^{\mathrm{a}}$ & $10.08 \pm 0.24 \mathrm{ab}$ \\
\hline Cd0.2 + Cu200 & $3252 \pm 96^{a}$ & $4237 \pm 56^{a b}$ & $4532 \pm 77^{a}$ & $10.36 \pm 0.12^{a b}$ \\
\hline $\mathrm{Cd} 2.0+\mathrm{Cu} 200$ & $3340 \pm 137^{a}$ & $4307 \pm 288^{a}$ & $4683 \pm 308^{a}$ & $10.31 \pm 0.25^{a b}$ \\
\hline $\mathrm{Cd} 20+\mathrm{Cu} 200$ & $3149 \pm 415^{a}$ & $3756 \pm 795^{a b}$ & $4095 \pm 901^{a}$ & $10.36 \pm 0.22^{a b}$ \\
\hline $\mathrm{Cd} 0.2+\mathrm{Cu} 400$ & $3201 \pm 169^{a}$ & $4095 \pm 3244^{a b}$ & $4461 \pm 265^{a}$ & $10.24 \pm 0.27^{a b}$ \\
\hline $\mathrm{Cd} 2.0+\mathrm{Cu} 400$ & $3407 \pm 42^{a}$ & $4093 \pm 82^{a b}$ & $4493 \pm 100^{a}$ & $10.54 \pm 0.51^{a b}$ \\
\hline $\mathrm{Cd} 20+\mathrm{Cu} 400$ & $3224 \pm 34^{a}$ & $3972 \pm 185^{a b}$ & $4354 \pm 116^{a}$ & $10.34 \pm 0.10^{a b}$ \\
\hline
\end{tabular}

Note: Each number in the table represents the average value of three measurements; Different letters in the upper right corner denote significant differences among treatments $(p<0.05)$. 

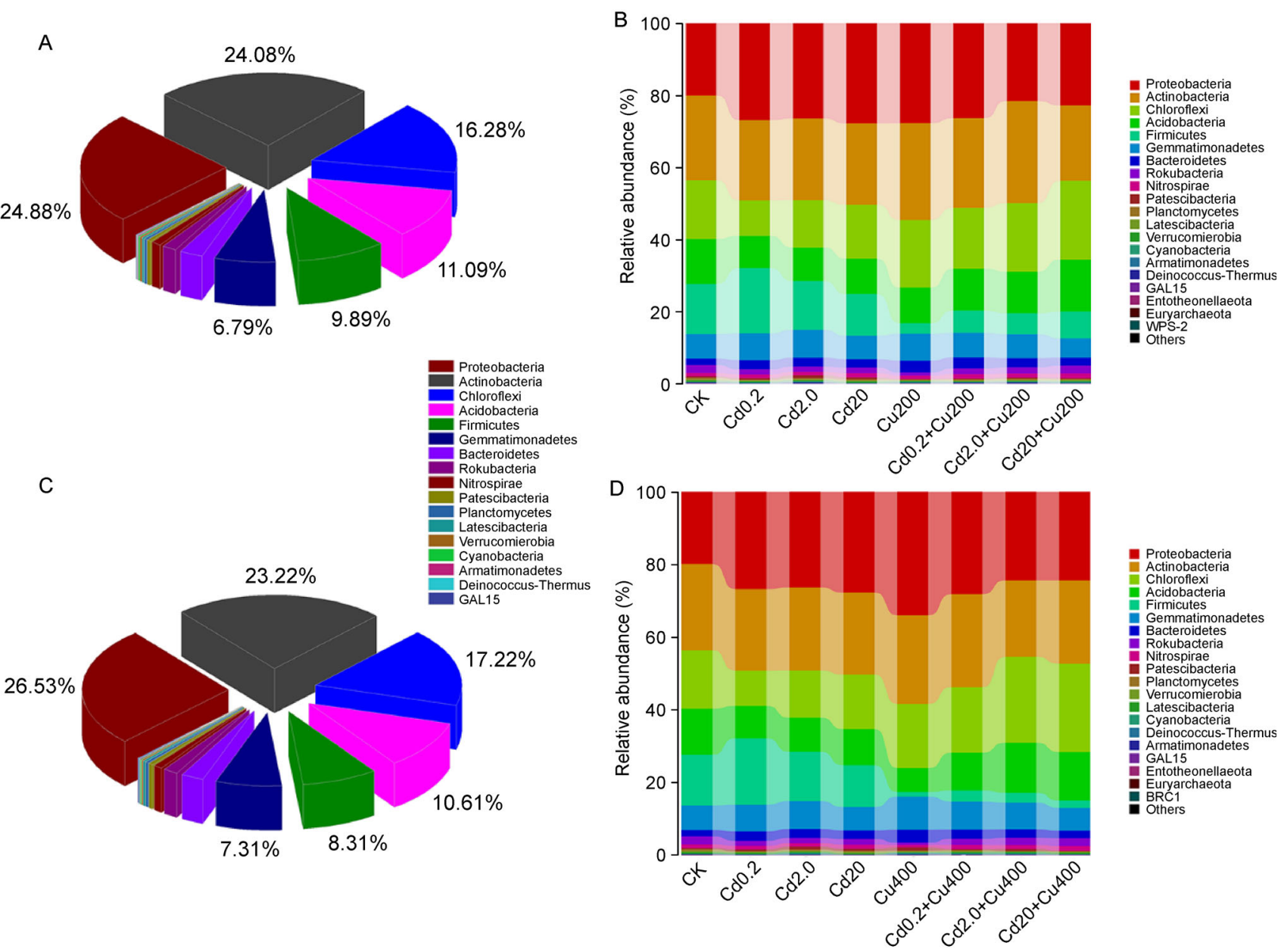

Fig. 2 Relative abundance of bacteria at phylum level. (A, C: Percentage of bacterial relative abundance of all treatments; B, D: Relative abundance of bacteria under different treatment. A, B: Treatment of Cd $\left(0,0.2,2,20 \mathrm{mg} \mathrm{kg}^{-1}\right)+\mathrm{Cu}\left(0,200 \mathrm{mg} \mathrm{kg}^{-1}\right) ; \mathrm{C}, \mathrm{D}$ : Treatment of Cd $(0$, $\left.\left.0.2,2,20 \mathrm{mg} \mathrm{kg}^{-1}\right)+\mathrm{Cu}\left(0,400 \mathrm{mg} \mathrm{kg}^{-1}\right)\right)$.

At the genus level, of these, Streptomyces belonging to Actinobacteria as biomarkers was significantly enriched in the control $(p<0.05)$. In the additions with only $\mathrm{Cd}$ or $\mathrm{Cu}$ (Fig. 3A and $3 \mathrm{~B})$, because of significant enrichment $(p<0.05)$, the following were identified as biomarkers: Aquabacterium (belonging to Proteobacteria), Bacillus (belonging to Firmicutes) and Micromonospora (belonging to Actinobacteria) in Cd 0.2 treatment; Fictibacillus (belonging to Firmicutes) in the Cd 2 treatment $(p<0.05)$; Paenibacillus (belonging to Firmicutes), Roseomonas and Variovorax (belonging to Proteobacteria) in the Cd 20 treatment; Arthrobacter (belonging to Actinobacteria), Ferrovibrio, Sphingopyxis, Cupriavidus and Pseudoxanthomonas (belonging to Proteobacteria) in the $\mathrm{Cu}$ 200 treatment; Microbacterium (belonging to Actinobacteria), Sphingopyxis, Cupriavidus, Rhodanobacter and Pseudoxanthomonas (belonging to Proteobacteria) in the $\mathrm{Cu} 400$ treatment. In the additions with $\mathrm{Cd}$ and $\mathrm{Cu}$ mixtures (Fig. $3 \mathrm{~A}$ and $3 \mathrm{~B})$, because of significant enrichment $(p<0.05)$, the following were identified as biomarkers: Arthrobacter (belonging to Actinobacteria) in the treatment of $\mathrm{Cd} 0.2+\mathrm{Cu} 400$;
Pseudarthrobacter (belonging to Actinobacteria) in the treatment of Cd $2+\mathrm{Cu} 200$ ( $p<0.05$ ); Vicinamibacter (belonging to Acidobacteria), Afipia (belonging to Proteobacteria), in the treatment of $\mathrm{Cd} 2+\mathrm{Cu} 400$; Microbacterium (belonging to Actinobacteria), in the treatment of $\mathrm{Cd} 20+\mathrm{Cu} 200$; Hydrogenispora and Methlobacillus (belonging to Firmicutes), Rhodopseudomonas, Ferrovibrio and Altererythrobacter (belonging to Proteobacteria) in the treatment of $\mathrm{Cd} 20+\mathrm{Cu}$ 400. These results indicated the predominant taxa of rhizosphere bacterial communities were affected by additions with different concentrations of $\mathrm{Cd}-\mathrm{Cu}$ mixtures.

\subsection{Beta diversity of the bacterial communities}

The unweighted UniFrac NMDS based on OTUs and relative abundance showed that the single and mixed $\mathrm{Cd}$ and $\mathrm{Cu}$ treatments affected rhizosphere bacterial communities (Fig. 4A and 4B). In the treatments with $\mathrm{Cd}(0,0.2,2.0$, $\left.20 \mathrm{mg} \mathrm{kg}^{-1}\right)+\mathrm{Cu}\left(200 \mathrm{mg} \mathrm{kg}^{-1}\right)$, the distance among the mixed treatments was smaller than that among other 


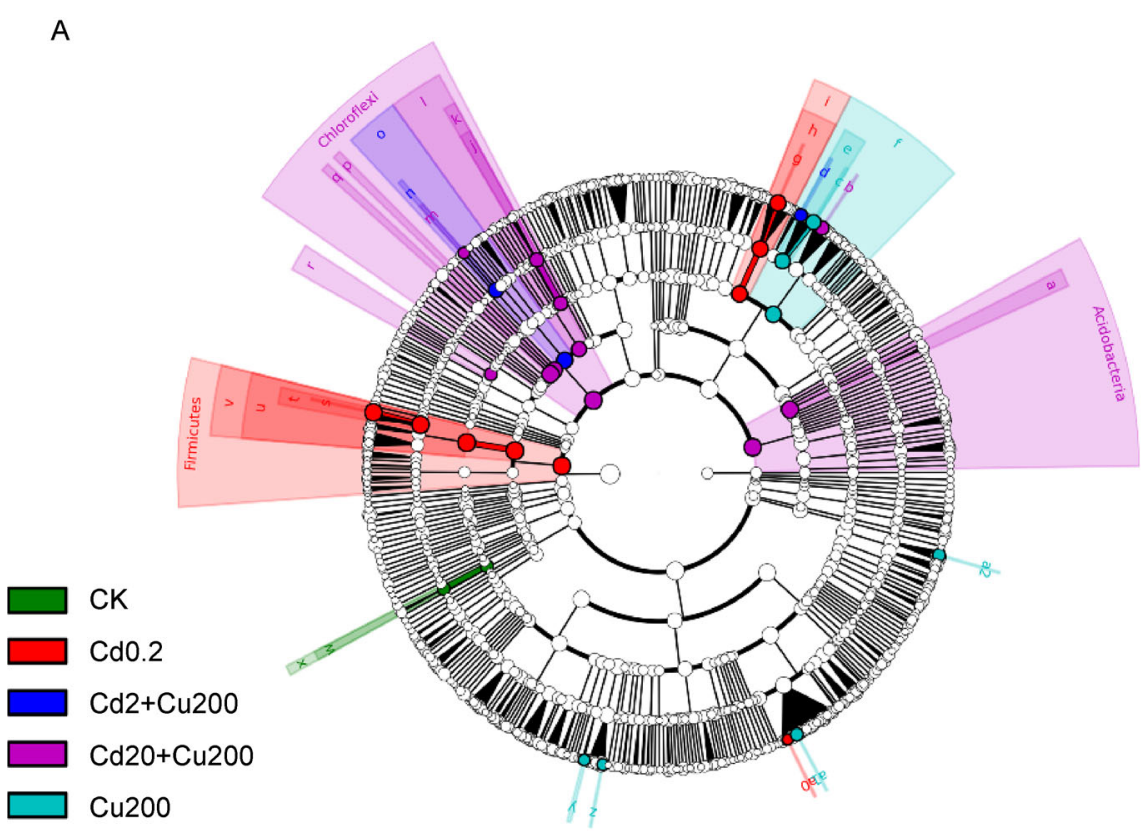

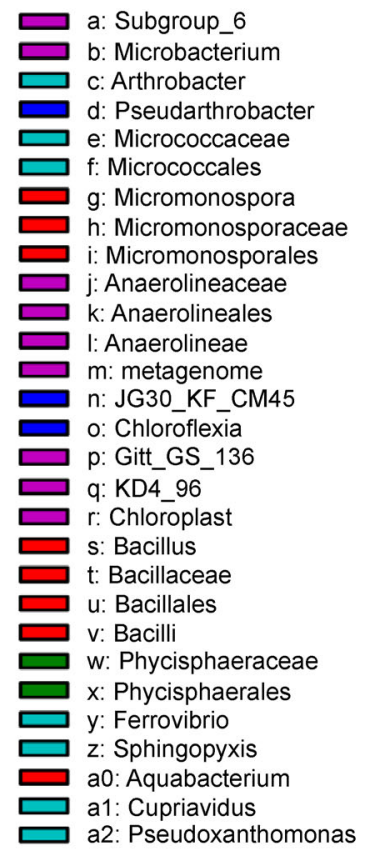
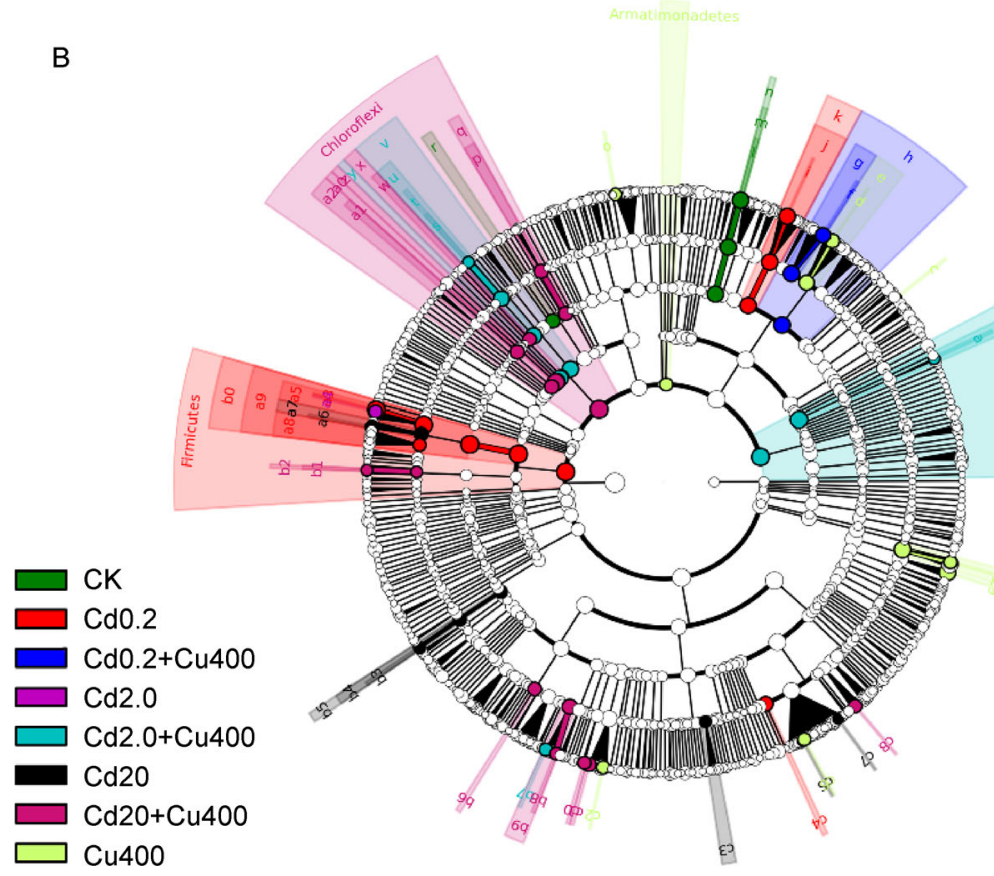

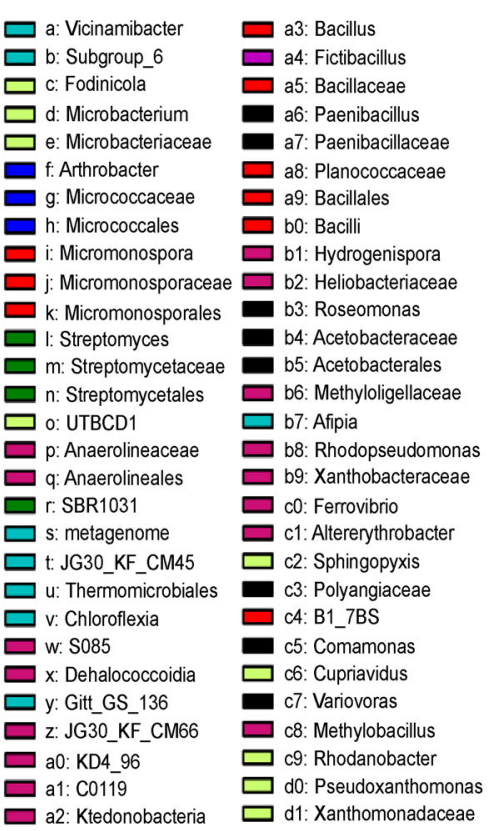

Fig. 3 Taxonomic dendrogram of biomarker bacteria (A: Treatments of CK, Cd0.2 and Cd $\left(0,2,20 \mathrm{mg} \mathrm{kg}^{-1}\right)+\mathrm{Cu}\left(200 \mathrm{mg} \mathrm{kg}^{-1}\right)$; B: Treatments of $\left.\left.\mathrm{Cd}\left(0,0.2,2,20 \mathrm{mg} \mathrm{kg}^{-1}\right)+\mathrm{Cu} 0,400 \mathrm{mg} \mathrm{kg}^{-1}\right)\right)$. The circle diameter is proportional to the taxon abundance, and each ring represents a taxonomic level in order from the center to the periphery: phylum, class, order, family, and genus.

treatments. The distance between $\mathrm{CK}$ and heavy metal treatments was relatively large, and therefore, they could not be considered a cluster (Fig. 4A). Thus, compared with the $\mathrm{CK}$, the additions of $\mathrm{Cd}$ and $\mathrm{Cu}$ changed the abundance of soil bacteria and shaped the structure of rhizosphere bacterial communities. The results in $\mathrm{Cd}\left(0,0.2,2.0,20 \mathrm{mg} \mathrm{kg}^{-1}\right)+\mathrm{Cu}$ $\left(400 \mathrm{mg} \mathrm{kg}^{-1}\right.$ ) treatment (Fig. 4B) were similar to those with $\mathrm{Cu}$ at $200 \mathrm{mg} \mathrm{kg}^{-1}$ (Fig. 4A). However, the difference among mixed treatments was greater.

PCA was used to assess the degree to which $\mathrm{Cd}$ and $\mathrm{Cu}$ 

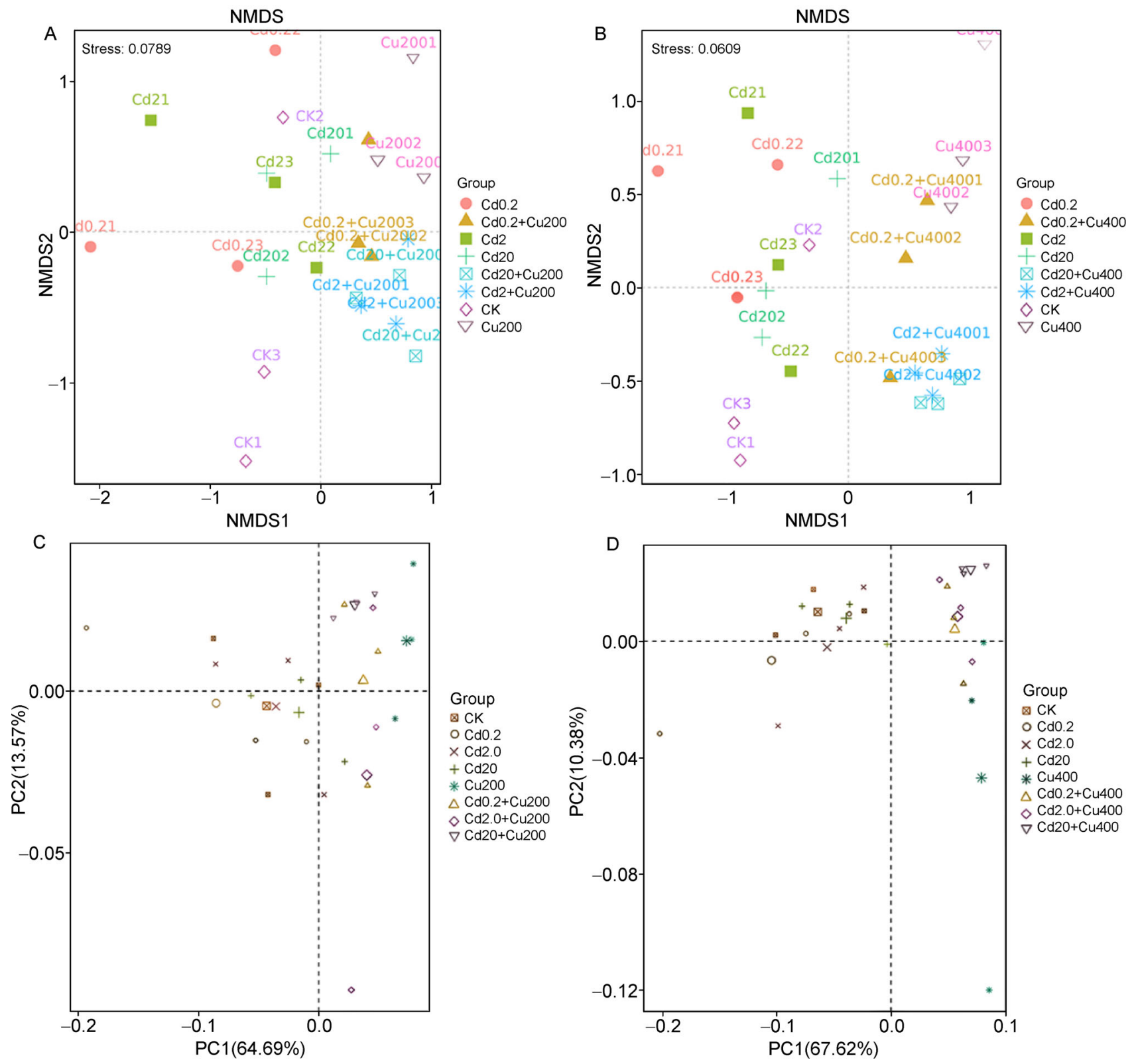

Fig. 4 Beta diversity of rhizosphere soil bacterial community. (A, B: Ordination plot of treatments according to unweighted UniFrac NMDS based on relative abundance bacteria taxa at OTU level in rhizosphere soil; C, D: PCA based on the composition structure of rhizosphere soil microbial community at the genus level. A, C: Treatments of $\mathrm{Cd}\left(0,0.2,2,20 \mathrm{mg} \mathrm{kg}^{-1}\right)+\mathrm{Cu}\left(0,200 \mathrm{mg} \mathrm{kg}^{-1}\right) ; \mathrm{B}, \mathrm{D}: \mathrm{Treatments}$ of Cd $(0,0.2,2$, $\left.\left.20 \mathrm{mg} \mathrm{kg}^{-1}\right)+\mathrm{Cu}\left(0,400 \mathrm{mg} \mathrm{kg}^{-1}\right)\right)$.

affected the richness and diversity of rhizosphere bacteria (Fig. $4 \mathrm{C}$ and $4 \mathrm{D}$ ). Figure $4 \mathrm{C}$ shows the PCA of single or mixtures of $\mathrm{Cd}\left(0.2,2.0,20 \mathrm{mg} \mathrm{kg}^{-1}\right)$ and $\mathrm{Cu}\left(200 \mathrm{mg} \mathrm{kg}^{-1}\right)$ treatments. Two principal components with eigenvalues greater than 1 were extracted, which explained $78.26 \%$ of the changes in the composition of the rhizosphere bacterial community. On the basis of the communalities obtained in the analysis, the use of only two components to represent the variables was adequate. The distance between all single $\mathrm{Cd}$ additions and $\mathrm{CK}$ was smaller than that among the other treatments (Fig. 4C), which indicated that the composition of rhizosphere bacteria was similar between Cd only treatment and CK. According to the PCA, with the addition of $200 \mathrm{mg} \mathrm{kg}^{-1} \mathrm{Cu}$, the treatments of $200 \mathrm{mg} \mathrm{kg}^{-1} \mathrm{Cu}$ and the three mixed groups clustered together. Simultaneously, the distance increased between those treatments and $\mathrm{CK}$ (Fig. 4C). The PERMANOVA results (Table 3) confirmed those obtained in the PCA, with significant differences detected among treatments $(p=0.002)$. Figure 4D shows the PCA of single or mixtures of $\mathrm{Cd}$ and $400 \mathrm{mg} \mathrm{kg}^{-1} \mathrm{Cu}$. The results were similar to that of Fig. 4C. PERMANOVA results (Table 3) also detected significant differences among 
Table 3 p-values and F-values generated from one-way PERMANOVA of Bray-Crutis similarity indices among treatments.

\begin{tabular}{llll}
\hline Treatments & Degree of freedom & $p$-value & F-value \\
\hline A & 3 & 0.861 & 0.6853 \\
B & 3 & $0.001^{* *}$ & 3.6329 \\
C & 7 & $0.002^{* *}$ & 2.6894 \\
D & 7 & $0.002^{* *}$ & 2.6660 \\
E & 7 & $0.001^{* *}$ & 3.3950 \\
F & 7 & $0.002^{* *}$ & 1.9063 \\
G & 7 & $0.001^{* *}$ & 3.0055 \\
\hline
\end{tabular}

Note: A: Treatments of Cd $\left(0,0.2,2,20 \mathrm{mg} \mathrm{kg}^{-1}\right)$; B: Treatments of Cu $\left(0,200,400 \mathrm{mg} \mathrm{kg}^{-1}\right)$; C: Treatments of Cd $\left(0,0.2 \mathrm{mg} \mathrm{kg}^{-1}\right)+\mathrm{Cu}(0,200,400$ $\left.\mathrm{mg} \mathrm{kg}^{-1}\right)$; D: Treatments of Cd $\left(0,2 \mathrm{mg} \mathrm{kg}^{-1}\right)+\mathrm{Cu}\left(0,200,400 \mathrm{mg} \mathrm{kg}^{-1}\right)$; E: Treatments of Cd $\left(0,20 \mathrm{mg} \mathrm{kg}^{-1}\right)+\mathrm{Cu}\left(0,200,400 \mathrm{mg} \mathrm{kg}{ }^{-1}\right) ; \mathrm{F}$ : Treatments of $\mathrm{Cd}\left(0,0.2,2,20 \mathrm{mg} \mathrm{kg}^{-1}\right)+\mathrm{Cu}\left(0,200 \mathrm{mg} \mathrm{kg}^{-1}\right)$; G: Treatments of $\mathrm{Cd}\left(0,0.2,2,20 \mathrm{mg} \mathrm{kg}^{-1}\right)+\mathrm{Cu}\left(0,400 \mathrm{mg} \mathrm{kg}^{-1}\right)$. ${ }^{* \star} \mathrm{Correlation}$ is significant at 0.01 levels.

treatments $(p=0.001)$. Remarkably, according to the PERMANOVA, there was no significant difference among treatments with the addition of only $\mathrm{Cd}(p=0.861$; Table 3$)$.

\section{Discussion}

4.1 Effects of $\mathrm{Cd}$ and $\mathrm{Cu}$ additions on the diversity and structure of rhizosphere bacterial community

In this study, with all possible shared and unique relationships among the five treatments of samples, more than 30 partitions observed in the Venn diagram. The addition of other treatments would overcrowd the diagram and sharply increase the complexity and greatly reduce the readability. To avoid the problem of too many treatments, most studies select specific treatments for comparison in Venn diagram $(\mathrm{He}$ et al., 2017; Yu et al., 2020). Therefore, in this study, the treatments of $\mathrm{Cd}\left(0.2,20 \mathrm{mg} \mathrm{kg}^{-1}\right)+\mathrm{Cu}\left(200 \mathrm{mg} \mathrm{kg}^{-1}\right)$ were selected to examine the effects of high and low concentrations of $\mathrm{Cd}$ combined with $\mathrm{Cu}$ (Fig. 1A); To study the effects of $\mathrm{Cd}$ or $\mathrm{Cu}$ alone, Cd low (0.2 mg kg-1) and high (20 mg kg-1) concentrations and the $\mathrm{Cu}\left(400 \mathrm{mg} \mathrm{kg}^{-1}\right)$ high concentration were selected (Fig. 1B). According to He et al. (2017), shared OTUs can potentially delineate the core rhizosphere microbiome of a soil sample set. Therefore, in this study, the results in the Venn diagram might be explained by bacterial adaptation to soils with different concentrations of $\mathrm{Cd}-\mathrm{Cu}$ mixtures contamination.

Richness and diversity indices, such as Chao1, ACE and Shannon indices, are used to evaluate the abundance, and evenness of biological communities (Sánchez-Moreno and Navas, 2007; Yuebing et al., 2020). In this study, the Shannon index in different treatments was similar, indicating that the evenness in bacterial communities was similar among treatments (Table 2). The results are consistent with those of previous studies, and Will et al. (2010) and Nacke et al. (2011) found that with the additions of lead and zinc, the species diversity of bacterial communities in polluted soils was similar to that in unpolluted soils. In the additions with single and mixtures of $\mathrm{Cd}$ and $\mathrm{Cu}$, the richness indice, Chao1 and ACE, showed different degrees of change (Table 2). Exposure to $\mathrm{Cd}$ or $\mathrm{Cu}$ decreased the richness of rhizosphere bacterial communities. In the treatments with $\mathrm{Cd}$-Cu mixtures, an antagonistic relation between $\mathrm{Cd}$ and $\mathrm{Cu}$ might have occurred, which reduced the toxic effects of heavy metals on soil bacteria. Sun et al. (2020) also found that exposure to heavy metal pollution affects the abundance, structure, diversity and uniformity of bacterial communities. In addition, Chodak et al. (2013) found that the diversity of soil bacteria (Chao1) was negatively affected by heavy metal pollution. With combinations of heavy metals, there can be antagonistic or synergistic effects that are related to their concentrations (Lanier et al., 2019).

According to the analysis of bacterial community beta diversity, compared with the $\mathrm{CK}$, the addition of $\mathrm{Cu}$ might be the primary factor that altered the composition of rhizosphere bacterial communities (Fig. 4, Table 3). High concentrations of Cu can affect the numbers, biomass, activity and composition of soil microbial communities (Wang et al., 2007; FernándezCalviño et al., 2012; Song et al., 2018). Xu et al. (2015) studied the effects of $\mathrm{TiO}_{2}$ and $\mathrm{CuO}$ nanoparticles on the community structure of soil microbes in flooded paddy soil, the results showed that $\mathrm{CuO}$ nanoparticles was the major factor that reduced the composition and diversity of soil microbial community, and the authors speculated that the bioavailability of $\mathrm{CuO}$ nanoparticles increased the toxicity to microbes. The $\mathrm{CuO}$ nanoparticles may have also indirectly affected soil microbes by changing nutrient bioavailability. The formation of reactive oxygen species and the subsequent oxidative stress are the likely mechanisms causing changes in microbial community structure at high concentrations of $\mathrm{Cu}$, which also leads to the oxidation of proteins, DNA and lipids and ultimately cell death (Li et al., 2014). However, this does not mean that $\mathrm{Cd}$ has no effect on the structural changes of rhizosphere microorganisms in soil, though competition and 
antagonism of $\mathrm{Cd}$ and $\mathrm{Cu}$ in soil, $\mathrm{Cu}$ and $\mathrm{Cd}$ play a synergistic role in the change of bacterial community. Exchangeable $\mathrm{Cd}$ has strong mobility in surface layer $(0$ to $15 \mathrm{~cm})$ and cannot be degraded by microorganisms (Zia et al., 2018). Cd also indirectly affects the richness and structure of rhizosphere microbial communities by affecting soil respiration and metabolism (Vig et al., 2003).

\subsection{Effects of $\mathrm{Cd}$ and $\mathrm{Cu}$ additions on the abundance of dominant bacteria}

The relative abundance of Preteobacteria is positively correlated with $\mathrm{Cu}$ and zinc pollution (Feris et al., 2003; Yan et al., 2020). According to Feris et al. (2003), the Proteobacteria have the strongest tolerance to heavy metals, and can even increase in abundance at certain concentrations. The results in this study are consistent with those of previous research. In the treatments with heavy metals, there were changes in rhizosphere soil bacterial communities, and the relative abundance of Proteobacteria increased (Fig. 2). The phylum Proteobacteria is one of the most abundant and widespread phyla of soil bacteria (Narendrula-Kotha and Nkongolo, 2017), It is also the dominant phylum of bacteria in heavy metal contaminated soil (Idris et al., 2004; Song et al., $2018 b)$. The predominant bacterial phyla observed in this study are similar to those in observed in other heavy metal contaminated soils (Liu et al., 2015; Zhang et al., 2016).

In this study, Firmicutes $(7.20 \%-28.5 \%)$ was the dominant phylum in the rhizosphere with the addition of $\mathrm{Cd}$ only, however, it was not with the addition of $\mathrm{Cu}$ (Fig. 2). Similarly, Ferreira et al. (2015) found that $\mathrm{Cu}$ inhibits the growth thermophilic bacterial communities in the Firmicutes. Therefore, the results of this study and those of Ferreira et al. (2015) suggest that members of the Firmicutes are sensitive to the addition of $\mathrm{Cu}$, and may be inhibited by high concentration. $\mathrm{Cu}$ is a micronutrient required for multiple metal-dependent enzymes but at higher concentrations it presents toxicity (Ferreira et al., 2015). Study has found that excess copper avidly binds to many biomolecules such as proteins, lipids, and nucleic acids, regardless of its valence state (Solioz et al., 2010). But compared to other toxic metals such as Cd and lead, $\mathrm{Cu}$ is an essential trace nutrient. So bacteria evolved tight copper homeostatic control mechanisms, involving copper binding and transport and the regulation of gene expression by copper (Solioz et al., 2010).

4.3 Identification of biomarkers in rhizosphere bacterial communities in single and mixture additions with of $\mathrm{Cd}$ and $\mathrm{Cu}$

The organisms that passed the pairwise Wilcoxon test were defined as biomarkers (Jiao et al., 2018). LEfSe analysis (linear discriminative analysis (LDA) coupled with effect size measurement for significant differences) is effective method for identifying biomarkers (Zhang et al., 2018; Wang et al., 2020). Heavy metals have important effects on the structure of rhizosphere and endophytic microbial communities (Lin et al.,
2021). Study has showed that the richness of Actinobacteria was found corresponding to the variation of soil physicochemical characters (Yu et al., 2020). The results in this study are consistent with those of previous studies (Zhang et al., 2016; Yu et al., 2020). The Actinobacteria genera Streptomyces, Micromonospora, Arthrobacter and Microbacterium were significantly enriched in contaminated or uncontaminated soil (Fig. $3 \mathrm{~A}$ and $3 \mathrm{~B}$ ). The results demonstrate the important role of the phylum Actinobacteria in providing biomarker in bacterial communities (Zhou et al., 2011; Yu et al., 2020). In addition, Proteobacteria are the most tolerant to heavy metals, and their relative abundance can even slightly increase at certain metal concentration (Feris et al., 2003; Lin et al., 2021). In this paper, compared with CK, in the treatments with heavy metal additions, some genera of Proteobacteria were enriched to varying degrees, including Micromonospora, Roseomonas, Pseudoxanthomonas and Rhodopseudomonas (Fig. 3A and 3B). Those genera are heavy metal resistant and ecologically beneficial and therefore, could promote plant growth and facilitate phytoremediation (Liu et al., 2018; Lin et al., 2021). Our results were consistent with those of Lin et al. (2021) who also found that some genera of Proteobacteria are significantly enriched in different degrees under heavy metal stress, including Kaistobacter, Lysobacter, Cellvibrio and Pseudomonas. Besides, some genera in the Firmicutes, such as Bacillus were enriched in the additions with $\mathrm{Cd}$ only, while there was no significantly difference in the additions with Cu only (Fig. 3A and $3 \mathrm{~B}$ ). We speculated the reason may be that Firmcutes is sensitive to the addition of $\mathrm{Cu}$, and the high concentration of Cu may inhibit the Firmcutes (Ferreira et al., 2015). Study has found that Bacillus could promote plant growth (Lin et al., 2021), and in this study, in the addition with single Cd, Bacillus was enriched. This indicated that rhizosphere bacterial community may protect plants from heavy metals by enriching Bacillus. In addition to the enrichment of genera in the Actinobacteria and Proteobacteria in the additions with $\mathrm{Cd}-\mathrm{Cu}$ mixtures, some genera in the Firmicutes were also enriched, including Hydrogenispora and Methlobacillus (Fig. 3A and 3B). Therefore, at different concentrations, there might be antagonistic interaction between $\mathrm{Cd}$ and $\mathrm{Cu}$ that alleviated the inhibitory effect of $\mathrm{Cu}$ on the Firmicutes. The reason may be that heavy metal coordination sites on the cell surface are not specific for a single metal, and competition for membrane transport sites and intracellular binding sites can occur for metals with similar ionic radii and coordination geometry (Sunda and Huntsman, 1998). The emergence of antagonism and synergism between metals at different concentrations has been observed previously (He et al., 2004; Wang et al., 2015; Cai et al., 2019).

\section{Conclusion}

The effects of the addition of either $\mathrm{Cd}$ or $\mathrm{Cu}$, or mixtures of the two, on the abundance and structure of rhizosphere bacterial 
communities were examined in this study. The results showed that in the addition of $\mathrm{Cd}\left(20 \mathrm{mg} \mathrm{kg}^{-1}\right)+\mathrm{Cu}\left(400 \mathrm{mg} \mathrm{kg}^{-1}\right)$ mixture, the dominant phyla of bacteria were Proteobacteria, Actinobacteria, Chloroflexi and Acidobacteria. In the additions with single and mixture of $\mathrm{Cd}$ and $\mathrm{Cu}$, compared with $\mathrm{CK}$, the genera Pseudoxanthomonas and Rhodopseudomonas in the Proteobacteria as biomarkers were enriched to varying degrees. In addition, it is worthy that in the additions with $\mathrm{Cd}$-Cu mixtures, beside the bacteria belonging to Proteobacteria, the genera Hydrogenispora and Methlobacillus in the Firmicutes were also identified as biomarkers because of significant enrichment. The PCA and PERMANOVA showed there were significant differences among treatments $(p<0.01)$, and that the addition of Cu might be the primary factor affecting the composition of rhizosphere bacterial communities. Cu may affect bacterial communities because it not only binds to enzyme molecules, but also to enzyme substrate complexes, and decrease of enzyme activity, heavy metal pollution will affect the absorption of heavy metals by plants. The result indicated that rhizosphere soil microorganisms participate in the mechanism of promoting plant growth, the number of rhizosphere soil microorganisms is not only related to the types and concentration of heavy metals, but also to their tolerance. At the same time, the rhizosphere soil microbial abundance was also related to the plants planted. The results of this study have increased understanding of the mechanisms of $\mathrm{Cd}$ and $\mathrm{Cu}$ toxicity to rhizosphere microorganisms, and thus can provide a new theoretical basis for the remediation of metal contaminated soil and plant management.

\section{Authorship contribution}

Qirui An: Performed the most of the experiments, writing-original draft. Yuyang Li: Performed the part of the experiments. $\mathrm{Na}$ Zheng: Funding acquisition, writing-review and editing, and supervision. Jincai Ma and Chunmei Zhao: Formal analysis, and supervision. Sujing Wang and Siyu Sun: Software. Pengyang Li: Formal analysis. Xiaoqian Li and Shengnan Hou: Conceptualization.

\section{Declaration of competing interest}

The authors declare that they have no known competing financial interests or personal relationships that could have appeared to influence the work reported in this paper.

\section{Acknowledgment}

The authors would like to acknowledge the support of the National Natural Science Foundation of China (41722110), the Leading Talents and Team Project of Scientific and Technological Innovation for young and Middle-aged Group in Jilin Province (20200301015RQ), the Major Special Program of Scientific and Technological of Jilin Province (20200503003SF), and the Research Fund Program of Guangdong Provincial Key
Laboratory of Environmental Pollution Control and Remediation Technology (2020B1212060022).

\section{References}

An, Y.J., Kim, Y.M., Kwon, T.I., Jeong, S.W., 2004. Combined effect of copper, cadmium, and lead upon Cucumis sativus growth and bioaccumulation. Science of the Total Environment 326, 85-93.

Anjum, S.A., Tanveer, M., Hussain, S., Bao, M., Wang, L., Khan, I., Ullah, E., Tung, S.A., Samad, R.A., Shahzad, B., 2015. Cadmium toxicity in Maize (Zea mays L.): consequences on antioxidative systems, reactive oxygen species and cadmium accumulation. Environmental Science and Pollution Research International 22, 17022-17030.

Cai, Y., Xu, W., Wang, M., Chen, W., Li, X., Li, Y., Cai, Y., 2019. Mechanisms and uncertainties of $\mathrm{Zn}$ supply on regulating rice $\mathrm{Cd}$ uptake. Environmental Pollution 253, 959-965.

Chaudhuri, D., Tripathy, S., Veeresh, H., Powell, M.A., Hart, B.R., 2003. Relationship of chemical fractions of heavy metals with microbial and enzyme activities in sludge and ash-amended acid lateritic soil from India. Environmental Geology 45, 115-123.

Chodak, M., Gołebiewski, M., Morawska-Płoskonka, J., Kuduk, K., Niklińska, M., 2013. Diversity of microorganisms from forest soils differently polluted with heavy metals. Applied Soil Ecology 64, 7 14.

Chu, L., Liu, D.Y., Wang, Y.B., 2006. Separated and combined effects of $\mathrm{Cu}$ and $\mathrm{Cd}$ on seeding growth and active oxygen metaolism system of Trifolium repens L. Frontiers in Broscience-Landmark 11, 2861-2867.

Edgar, R.C., 2010. Search and clustering orders of magnitude faster than BLAST. Bioinformatics (Oxford, England) 26, 2460-2461.

Feng, J., Lin, Y., Yang, Y., Shen, Q., Huang, J., Wang, S., Zhu, X., Li, Z., 2018. Tolerance and bioaccumulation of $\mathrm{Cd}$ and $\mathrm{Cu}$ in Sesuvium portulacastrum. Ecotoxicology and Environmental Safety $147,306-312$.

Feris, K., Ramsey, P., Frazar, C., Moore, J.N., Gannon, J.E., Holben, W.E., 2003. Differences in hyporheic-zone microbial community structure along a heavy-metal contamination gradient. Applied and Environmental Microbiology 69, 5563-5573.

Fernández-Calviño, D., Arias-Estévez, M., Díaz-Raviña, M., Bååth, E., 2012. Assessing the effects of $\mathrm{Cu}$ and $\mathrm{pH}$ on microorganisms in highly acidic vineyard soils. European Journal of Soil Science 63, 571-578.

Ferreira, R., Gaspar, H., Gonzalez, J.M., Clara, M.I., Santana, M.M., 2015. Copper and temperature modify microbial communities, ammonium and sulfate release in soil. Journal of Plant Nutrition and Soil Science 178, 953-962.

Gan, Y., Wang, L., Yang, G., Dai, J., Wang, R., Wang, W., 2017. Multiple factors impact the contents of heavy metals in vegetables in high natural background area of China. Chemosphere 184, 1388-1395.

Giller, K.E., Witter, E., McGrath, S.P., 2009. Heavy metals and soil microbes. Soil Biology \& Biochemistry 41, 2031-2037.

Gołebiewski, M., Deja-Sikora, E., Cichosz, M., Tretyn, A., Wróbel, B., 2014. 16S rDNA pyrosequencing analysis of bacterial community 
in heavy metals polluted soils. Microbial Ecology 67, 635-647.

Gong, Q., Wang, L., Dai, T., Zhou, J., Kang, Q., Chen, H., Li, K., Li, Z., 2019. Effects of copper on the growth, antioxidant enzymes and photosynthesis of spinach seedlings. Ecotoxicology and Environmental Safety $171,771-780$.

Greco, M., Sáez, C.A., Contreras, R.A., Rodríguez-Rojas, F., Bitonti, M.B., Brown, M.T., 2019. Cadmium and/or copper excess induce interdependent metal accumulation, DNA methylation, induction of metal chelators and antioxidant defences in the seagrass Zostera marina. Chemosphere 224, 111-119.

Guan, Y., Shao, C., Ju, M., 2014. Heavy metal contamination assessment and partition for industrial and mining gathering areas. International Journal of Environmental Research and Public Health 11, 7286-7303.

Guo, B., Hong, C., Tong, W., Xu, M., Huang, C., Yin, H., Lin, Y., Fu, Q., 2020. Health risk assessment of heavy metal pollution in a soil- rice system: a case study in the Jin-Qu Basin of China. Scientific Reports 10, 1-11.

Hansda, A., Kumar, V., Anshumali., 2017. Cu-resistant Kocuria sp. CRB15: a potential PGPR isolated from the dry tailing of Rakha copper mine. 3 Biotech, 7, 1-11.

He, H., Li, W., Yu, R., Ye, Z., 2017. Illumina-based analysis of bulk and rhizosphere soil bacterial communities in paddy fields under mixed heavy metal contamination. Pedosphere 27, 569-578.

He, P.P., Lv, X.Z., Wang, G.Y., 2004. Effects of Se and Zn supplementation on the antagonism against $\mathrm{Pb}$ and $\mathrm{Cd}$ in vegetables. Environment International 30, 167-172.

Hou, S., Zheng, N., Tang, L., Ji, X., 2018. Effects of cadmium and copper mixtures to carrot and pakchoi under greenhouse cultivation condition. Ecotoxicology and Environmental Safety 159, 172 181.

Huang, G., Liao, J., Han, Z., Li, J., Zhu, L., Lyu, G., Lu, L., Xie, Y., Ma, J., 2020. Interaction between fungal communities, soil properties, and the survival of invading E. coli $0157: \mathrm{H} 7$ in soils. International Journal of Environmental Research and Public Health 17, 1-17.

Idris, R., Trifonova, R., Puschenreiter, M., Wenzel, W.W., Sessitsch, A., 2004. Bacterial communities associated with flowering plants of the Ni hyperaccumulator Thlaspi goesingense. Applied and Environmental Microbiology 70, 2667-2677.

Jiang, B., Adebayo, A., Jia, J., Xing, Y., Deng, S., Guo, L., Liang, Y., Zhang, D., 2019. Impacts of heavy metals and soil properties at a Nigerian e-waste site on soil microbial community. Journal of Hazardous Materials 362, 187-195.

Jiao, Y., Zhou, Z., Chen, T., Wei, Y., Zheng, J., Gao, R., Chen, H., 2018. Biomarkers of antibiotic resistance genes during seasonal changes in wastewater treatment systems. Environmental Pollution 234, 79-87.

Ju, W., Liu, L., Fang, L., Cui, Y., Duan, C., Wu, H., 2019. Impact of coinoculation with plant-growth-promoting rhizobacteria and rhizobium on the biochemical responses of alfalfa-soil system in copper contaminated soil. Ecotoxicology and Environmental Safety 167, 218-226.

Kidd, P., Barceló, J., Bernal, M.P., Navari-Izzo, F., Poschenrieder, C., Shilev, S., Clemente, R., Monterroso, C., 2009. Trace element behaviour at the root-soil interface: Implications in phytoremediation. Environmental and Experimental Botany 67, 243-259.
Lanier, C., Bernard, F., Dumez, S., Leclercq-Dransart, J., Lemière, S., Vandenbulcke, F., Nesslany, F., Platel, A., Devred, I., Hayet, A., Cuny, D., Deram, A., 2019. Combined toxic effects and DNA damage to two plant species exposed to binary metal mixtures (Cd/Pb). Ecotoxicology and Environmental Safety,167, 278-287.

Lauber, C.L., Strickland, M.S., Bradford, M.A., Fierer, N., 2008. The influence of soil properties on the structure of bacterial and fungal communities across land-use types. Soil Biology \& Biochemistry 40, 2407-2415.

Li, H., Liu, L., Luo, L., Liu, Y., Wei, J., Zhang, J., Yang, Y., Chen, A., Mao, Q., Zhou, Y., 2018. Response of soil microbial communities to red mud-based stabilizer remediation of cadmium-contaminated farmland. Environmental Science and Pollution Research International 25, 11661-11669.

Li, J., Zheng, Y.M., Liu, Y.R., Ma, Y.B., Hu, H.W., He, J.Z., 2014. Initial copper stress strengthens the resistance of soil microorganisms to a subsequent copper stress. Microbial Ecology 67, 931-941.

Lin, H., Liu, C., Li, B., Dong, Y., 2021. Trifolium repens L. regulated phytoremediation of heavy metal contaminated soil by promoting soil enzyme activities and beneficial rhizosphere associated microorganisms. Journal of Hazardous Materials 402, 123829.

Liu, C., Lin, H., Dong, Y., Li, B., Liu, Y., 2018. Ecotoxicology and environmental safety investigation on microbial community in remediation of lead-contaminated soil by Trifolium repens $\mathrm{L}$. Ecotoxicology and Environmental Safety 165, 52-60.

Liu, J., He, X.X., Lin, X.R., Chen, W.C., Zhou, Q.X., Shu, W.S., Huang, L.N., 2015. Ecological effects of combined pollution associated with e-waste recycling on the composition and diversity of soil microbial communities. Environmental Science \& Technology 49, 6438-6447.

Liu, X., Song, Q., Tang, Y., Li, W., Xu, J., Wu, J., Wang, F., Brookes, P. C., 2013. Human health risk assessment of heavy metals in soilvegetable system: A multi-medium analysis. Science of the Total Environment 463-464, 530-540.

Mani, D., Sharma, B., Kumar, C., Balak, S., 2012. Cadmium and lead bioaccumulation during growth stages alters sugar and vitamin $\mathrm{C}$ content in dietary vegetables. Proceedings of the National Academy of Sciences. India. Section B, Biological Sciences 82, 477-488.

Nacke, H., Thürmer, A., Wollherr, A., Will, C., Hodac, L., Herold, N., Schöning, I., Schrumpf, M., Daniel, R., 2011. Pyrosequencingbased assessment of bacterial community structure along different management types in German forest and grassland soils. PLoS One 6, e17000.

Narendrula-Kotha, R., Nkongolo, K.K., 2017. Bacterial and fungal community structure and diversity in a mining region under longterm metal exposure revealed by metagenomics sequencing. Ecological Genetics and Genomics 2, 13-24.

Roy, M., Mcdonald, L.M., 2015. Metal uptake in plants and health risk assessments in metal-contaminated smelter soils. Land Degradation \& Development 26, 785-792.

Sánchez-Moreno, S., Navas, A., 2007. Nematode diversity and food web condition in heavy metal polluted soils in a river basin in southern Spain. European Journal of Soil Biology 43, 166-179.

Schneider, A.R., Gommeaux, M., Duclercq, J., Fanin, N., Conreux, A., Alahmad, A., Lacoux, J., Roger, D., Spicher, F., Ponthieu, M., 
Cancès, B., Morvan, X., Marin, B., 2017. Response of bacterial communities to $\mathrm{Pb}$ smelter pollution in contrasting soils. Science of the Total Environment 605-606, 436-444.

Shi, Z., Zhang, Z., Yuan, M., Wang, S., Yang, M., Yao, Q., Ba, W., Zhao, J., Xie, B., 2020. Characterization of a high cadmium accumulating soil bacterium, Cupriavidus $\mathrm{sp}$. WS2. Chemosphere $247,125834$.

Siripornadulsil, S., Siripornadulsil, W., 2013. Cadmium-tolerant bacteria reduce the uptake of cadmium in rice: Potential for microbial bioremediation. Ecotoxicology and Environmental Safety 94, 94-103.

Solioz, M., Abicht, H.K., Mermod, M., Mancini, S., 2010. Response of Gram-positive bacteria to copper stress. Journal of Biological Inorganic Chemistry 15, 3-14.

Song, J., Shen, Q., Wang, L., Qiu, G., Shi, J., Xu, J., Brookes, P.C., Liu, X., 2018a. Effects of Cd, Cu, Zn and their combined action on microbial biomass and bacterial community structure. Environmental Pollution 243, 510-518.

Sun, C., Liu, J., Wang, Y., Sun, L., Yu, H., 2013. Multivariate and geostatistical analyses of the spatial distribution and sources of heavy metals in agricultural soil in Dehui, Northeast China. Chemosphere 92, 517-523.

Sun, Y., Zhao, L., Li, X., Xu, H., Weng, L., Yang, L., Li, Y., 2020. Response of soil bacterial and fungal community structure succession to earthworm addition for bioremediation of metolachlor. Ecotoxicology and Environmental Safety, 189, 109926.

Sunda, W. G., Huntsman, S. A., 1998. Processes regulating cellular metal accumulation and physiological effects: Phytoplankton as model systems. Science of The Total Environment 219, 165-181.

Tang, J., Zhang, J., Ren, L., Zhou, Y., Gao, J., Luo, L., Yang, Y., Peng, Q., Huang, H., Chen, A., 2019. Diagnosis of soil contamination using microbiological indices: A review on heavy metal pollution. Journal of Environmental Management 242, 121-130.

Teste, F.P., Kardol, P., Turner, B.L., Wardle, D.A., Zemunik, G., Renton, M., Laliberté, E., 2017. Plant-soil feedback and the maintenance of diversity in Mediterranean-climate shrublands. Science 355, 173-176.

Tian, P., Razavi, B. S., Zhang, X., Wang, Q., Blagodatskaya, E., 2020. Microbial growth and enzyme kinetics in rhizosphere hotspots are modulated by soil organics and nutrient availability. Soil Biology and Biochemistry 141, 107662.

Vig, K., Megharaj, M., Sethunathan, N., Naidu, R., 2003. Bioavailability and toxicity of cadmium to microorganisms and their activities in soil: A review. Advances in Environmental Research 8, 121-135.

Wang, Q., Hou, J., Yuan, J., Wu, Y., Liu, W., Luo, Y., Christie, P., 2020. Evaluation of fatty acid derivatives in the remediation of aged PAHcontaminated soil and microbial community and degradation gene response. Chemosphere 248, 125983.

Wang, Y., Chen, C., Qian, Y., Zhao, X., Wang, Q., Kong, X., 2015. Toxicity of mixtures of $\lambda$-cyhalothrin, imidacloprid and cadmium on the earthworm Eisenia fetida by combination index (Cl)-isobologram method. Ecotoxicology and Environmental Safety 111, 242247.

Wang, Y.P., Shi, J.Y., Wang, H., Lin, Q., Chen, X.C., Chen, Y.X., 2007. The influence of soil heavy metals pollution on soil microbial biomass, enzyme activity, and community composition near a copper smelter. Ecotoxicology and Environmental Safety 67, 7581.

Wenzel, W.W., 2009. Rhizosphere processes and management in plant-assisted bioremediation (phytoremediation) of soils. Plant and Soil 321, 385-408.

Will, C., Thürmer, A., Wollherr, A., Nacke, H., Herold, N., Schrumpf, M., Gutknecht, J., Wubet, T., Buscot, F., Daniell, R., 2010. Horizonspecific bacterial community composition of german grassland soils, as revealed by pyrosequencing-based analysis of $16 \mathrm{~S}$ rRNA genes. Applied and Environmental Microbiology 76, 6751-6759.

Wyszkowska, J., Borowik, A., Kucharski, M., Kucharski, J., 2013. Effect of cadmium, copper and zinc on plants, soil microorganisms and soil enzymes. Journal of Elementology 18, 769-796.

Xie, L., Hao, P., Cheng, Y., Ahmed, I.M., Cao, F., 2018. Effect of combined application of lead, cadmium, chromium and copper on grain, leaf and stem heavy metal contents at different growth stages in rice. Ecotoxicology and Environmental Safety 162, 71 76.

Xie, W., Zhou, J., Wang, H., Chen, X., Lu, Z., Yu, J., Chen, X., 2009. Short-term effects of copper, cadmium and cypermethrin on dehydrogenase activity and microbial functional diversity in soils after long-term mineral or organic fertilization. Agriculture, Ecosystems \& Environment 129, 450-456.

Xu, C., Peng, C., Sun, L., Zhang, S., Huang, H., Chen, Y., Shi, J., 2015. Distinctive effects of $\mathrm{TiO}_{2}$ and $\mathrm{CuO}$ nanoparticles on soil microbes and their community structures in flooded paddy soil. Soil Biology \& Biochemistry 86, 24-33.

Yan, C., Wang, F., Geng, H., Liu, H., Pu, S., Tian, Z., Chen, H., Zhou, B., Yuan, R., Yao, J., 2020. Integrating high-throughput sequencing and metagenome analysis to reveal the characteristic and resistance mechanism of microbial community in metal contaminated sediments. Science of the Total Environment 707, 136116.

Yang, W., Li, P., Rensing, C., Ni, W., Xing, S., 2019. Biomass, activity and structure of rhizosphere soil microbial community under different metallophytes in a mining site. Plant and Soil 434, 245262.

Yu, P., Sun, Y., Huang, Z., Zhu, F., Sun, Y., Jiang, L., 2020. The effects of ectomycorrhizal fungi on heavy metals' transport in Pinus massoniana and bacteria community in rhizosphere soil in mine tailing area. Journal of Hazardous Materials 381, 121203.

Yuebing, S., Shunan, Z., Lin, W., Xuefeng, L., Yingming, X., 2020. Changes of enzymatic activities, substrate utilization pattern, and microbial community diversity in heavy metal-contaminated soils. Water, Air, and Soil Pollution 231, 422.

Zhang, Q., Zhang, L., Liu, T., Liu, B., Huang, D., Zhu, Q., Xu, C., 2018. The influence of liming on cadmium accumulation in rice grains via iron-reducing bacteria. Science of the Total Environment 645, 109 118.

Zhang, W., Chen, L., Zhang, R., Lin, K., 2016. High throughput sequencing analysis of the joint effects of BDE209-Pb on soil bacterial community structure. Journal of Hazardous Materials 301, 1-7.

Zhao, X., Huang, J., Lu, J., Sun, Y., 2019. Study on the influence of soil microbial community on the long-term heavy metal pollution of different land use types and depth layers in mine. Ecotoxicology 
and Environmental Safety 170, 218-226.

Zhao, Z.B., He, J.Z., Quan, Z., Wu, C.F., Sheng, R., Zhang, L.M., Geisen, S., 2020. Fertilization changes soil microbiome functioning, especially phagotrophic protists. Soil Biology \& Biochemistry 148, 107863.

Zhou, J., Deng, Y., Luo, F., He, Z., Yanga, Y., 2011. Phylogenetic molecular ecological network of soil microbial communities in response to elevated $\mathrm{CO}_{2}$. mBio 2, 1-8.

Zhou, Q., Guo, J.J., He, C.T., Shen, C., Huang, Y.Y., Chen, J.X., Guo,
J.H., Yuan, J.G., Yang, Z.Y., 2016. Comparative transcriptome analysis between low- and high-cadmium-accumulating genotypes of pakchoi (Brassica chinensis L.) in response to cadmium stress. Environmental Science \& Technology 50, 6485-6494.

Zia, M., Rizwan, M., Hussain, A., Saqib, M., Ali, S., Irfan, M., Sha, M., 2018. Alleviation of cadmium (Cd) toxicity and minimizing its uptake in wheat (Triticum aestivum) by using organic carbon sources in Cd-spiked soil. Environmental Pollution 241, $557-565$ 